\title{
URGENSI PEMBENTUKAN PERATURAN DAERAH PROVINSI BALI TENTANG PERLINDUNGAN DAN PENGELOLAAN HUTAN MANGROVE BERLANDASKAN KEARIFAN LOKAL
}

\author{
Ahmad Redi ${ }^{1}$, Tundjung Herning Sitabuana ${ }^{2}$, Fakhrana Izazi Hanifati ${ }^{3}$, dan Putri Nabila \\ Kurnia Arsyad ${ }^{4}$ \\ ${ }^{1}$ Fakultas Hukum, Universitas Tarumanagara Jakarta \\ Email: ahmadr@fh.untar.ac.id \\ ${ }^{2}$ Fakultas Hukum, Universitas Tarumanagara Jakarta \\ Email: tundjung@fh.untar.ac.id \\ ${ }^{3}$ Fakultas Hukum, Universitas Tarumanagara Jakarta \\ Email: Fakhranaizazi@gmail.com \\ ${ }^{4}$ Fakultas Hukum, Universitas Tarumanagara Jakarta \\ Email: nabilaputriars@gmail.com
}

\begin{abstract}
ABSTRAK
Indonesia memiliki kekayaan sumber daya alam melimpah yang tersebar di 17.504 pulau salah satunya adalah hutan mangrove. Hutan mangrove sebaga bagian dari ekosistem memiliki banyak manfaat, diantaranya adalah sebagai penyerap karbon terbesar untuk melawan pemanasan global dan pemecah ombak sehingga meminimalisir abrasi. Salah satu wilayah Indonesia yang memiliki banyak hutan mangrove adalah Provinsi Bali. Namun, perlindungan dan pengelolaan hutan mangrove di Provisi Bali belum terlaksana dengan baik. Seperti adanya penyerobotan lahan kawasan hutan mangrove, pemanfaatan lahan untuk keperluan yang tidak sesuai peruntukkannya, perambahan, pencemaran, dan lain sebagainya. Meskipun terdapat regulasi yang membahas mengenai pengelolaan dari hutan mangrove, namun belum ada suatu payung hukum yang khusus membahas pemulihan ekosistem hutan mangrove yang mulai rusak. Sehingga diperlukan adanya suatu payung hukum dengan memperhatikan kearifan lokal masyarakat Provinsi Bali guna melindungi ekosistem hutan mangrove yang tetap sejalan dengan prinsip Tri Hita Karana. Tujuan penelitian ini adalah untuk memaparkan bagaimana urgensi pembentukan Peraturan Daerah Provinsi Bali tentang perlindungan dan pengelolaan hutan mangrove dengan menyesuaikan dengan kearifan lokal masyarakat Bali. Penelitian ini menggunakan metode penelitian hukum normatif empiris dengan studi literatur dan teknik wawancara In-Depth Interview. Hasil dari penelitian ini adalah telah terdapat berbagai regulasi nasional untuk melindungi dan mengelola hutan mangrove namun belum terdapat peraturan ditingkat daerah Provinsi Bali yang mengatur secara khusus padahal pada Tahun 2015 sebanyak 172 Ha Hutan Mangrove pada Kabupaten Badung telah rusak, kemudian pada Kabupaten Buleleng sebanyak 128,5 Ha Hutan Mangrove telah rusak yang dalam hal ini lebih banyak daripada jumlah hutan mangrove yang tidak rusak yakni 114,5 Ha, lalu pada Kota Denpasar hutan mangrove yang telah rusak adalah sebanyak 81,4 Ha, kemudian 63,5 Ha hutan mangrove di Jembrana juga telah rusak, dan Di Kabupaten Klungkung sebanyak 9,5 Ha telah rusak. Urgensi pembentukan peraturan daerah ini dapat dinilai sebagai realisasi Pasal 28H ayat (1) Undang-Undang Dasar Negara Republik Indonesia Tahun 1945. Kesimpulan penelitian ini adalah diperlukan untuk adanya suatu peraturan daerah yang mengatur mengenai pengelolaan dan pengawasan hutan mangrove di Bali dengan melibatkan masyarakat hukum adat, memuat ketentuan pidana, dilandaskan pada kearifan lokal Bali seperti Tri Hita Karana yang berarti tiga penyebab keharmonisan, terdiri dari parahyangan, pawongan dan palemahan.
\end{abstract}

Kata Kunci: Hutan Mangrove, Peraturan Daerah, Kearifan Lokal.

\section{ABSTRACT}

Indonesia possesses a wealth of abundant natural resources spread over 17,504 islands, one of which is mangrove forests. Mangrove forests as part of an ecosystem provides many benefits, including being the most effective carbon sink to combat global warming, and breaking incoming waves so as to minimize abrasion. One area of Indonesia with plenty of mangrove forests is the Province of Bali. However, the protection and management of mangrove forests in the Province of Bali has not been implemented well. Examples of which include land grabbing of the mangrove forest area, clearing said forest for uses that are not in accordance with its purpose, 
encroachment, pollution, and so forth. Despite regulations that discuss the management of mangrove forests, there is not yet a legal protection that specifically addresses the restoration of damaged mangrove forest. Therefore, legal protection with regards to the local wisdom of the people of Bali Province is necessary in order to protect the mangrove forest ecosystem which remains in line with the principles of Tri Hita Karana. The purpose of this study is to explain the urgency of the formation of the Bali Provincial Regulation concerning the protection and management of mangrove forests with regards to the local wisdom of the Balinese people. This research used empirical normative legal research method with literature studies and in-depth interview. The result of this study is that there have been various national regulations to protect and manage mangrove forests, however there is no regulation at the provincial level in Bali for similar purposes, whereas in 2015 as many as $172 \mathrm{Ha}$ of Mangrove Forest in Badung Regency was damaged, and then in Buleleng Regency $1285 \mathrm{Ha}$ of mangrove forest was damaged, which is more than the $114.5 \mathrm{Ha}$ of mangrove forest that is still undamaged. Then, in Denpasar, $81.4 \mathrm{Ha}$ of mangrove forest, in Jembrana, $63.5 \mathrm{Ha}$ of mangrove forest, and in Klungkung Regency $9.5 \mathrm{Ha}$ was damaged. The urgency of establishing this regional regulation can be seen as the realization of Article $28 \mathrm{H}$ paragraph (1) of the 1945 Constitution of the Republic of Indonesia. The conclusion of this study is that it is necessary for a regional regulation governing the management and supervision of mangrove forests in Bali by involving the customary law community, which contains criminal provisions, and based on Balinese local wisdom such as Tri Hita Karana which means three sources of harmony, consisting of parahyangan, pawongan and palemahan.

Keywords: Mangrove Forests, Regional Regulations, Local Wisdom.

\section{PENDAHULUAN}

\section{Latar Belakang}

Indonesia merupakan negara kepulauan terbesar di Dunia yang memiliki kekayaan sumber daya alam yang tersebar di 17.504 pulau, baik pulau besar maupun pulau kecil. Salah satu kekayaan alam Indonesia adalah hutan mangrove. Luas ekosistem hutan mangrove Indonesia adalah yang terluas di Dunia dengan keanekaragaman hayati yang sangat banyak. Diakses dari https://jurnalbumi.com/knol/hutan-mangrove pada tanggal 4 Agustus 2018, Hutan mangrove adalah ekosistem hutan daerah pantai yang terdiri dari kelompok pepohonan yang bisa hidup dalam lingkungan berkadar garam tinggi. Menurut data yang dikemukakan oleh Direktur Bina Pengelolaan Kawasan Ekosistem Esensial, Antung Deddy Radiansyah pada komunikasi publik di Gedung Manggala Wanabakti, Jakarta, Pada tanggal 14 Maret 2017, Indonesia mempunyai luas mangrove sebesar 3.489.140,68 Ha (tahun 2015). Jumlah ini setara dengan 23\% ekosistem mangrove dunia yaitu dari total luas 16.530 .000 ha. Dari luas mangrove di Indonesia, diketahui seluas 1.671.140,75 ha dalam kondisi baik, sedangkan areal sisanya seluas 1.817.999,93 ha sisanya dalam kondisi rusak. Ekosistem hutan mangrove memiliki fungsi yang sangat penting bagi keberlangsungan kehidupan, seperti melindungi pantai dari abrasi, sebagai pemecah gelombang laut, sebagai penahan lumpur dan sedimen, menjaga kestabilan garis pantai, menghasilkan destritus yang didapat dari daun dan pohon mangrove yang rontok, penghasil oksigen dan penyerap karbondioksida, sebagai pengolah limbah, menjadi suatu daerah asuhan (nursery ground), daerah pencari makanan (feeding ground) dan daerah pemijahan (spawning ground) bermacam biota perairan (ikan, udang dan kerang-kerangan) baik yang hidup di perairan maupun lepas pantai (Madjid et al., 2016).

Salah satu wilayah Indonesia yang memiliki banyak kawasan hutan mangrove adalah Provinsi Bali. Mangrove di Provinsi Bali sebagian besar tumbuh di dalam kawasan hutan, dengan sebaran terluas terdapat pada Taman Hutan Raya (Tahura) Ngurah Rai yaitu seluas 1.373,5 ha, sebagian di kawasan Taman Nasional Bali Barat yaitu seluas 633,5 ha dan di Kabupaten Klungkung (hutan lindung) seluas 202 ha (Pusat Pengendalian Pembangunan Ekoregion Bali dan Nusa Tenggara, 2015). Kawasan Hutan Mangrove di Provinsi Bali terbagi menjadi 2 jenis kawasan hutan, yakni Hutan Lindung dan Hutan Konservasi. Kawasan hutan mangrove yang dalam 
kategori hutan konservasi adalah Tahura Ngurah Rai, sedangkan hutan mangrove lainnya berada dalam kategori hutan lindung. Menilik Undang-Undang Nomor 5 Tahun 1990 tentang Konservasi Sumber Daya Alam Hayati dan Ekosistemnya, Taman Hutan Raya merupakan kawasan pelestarian alam dengan tujuan koleksi tumbuhan dan atau satwa yang alami atau buatan, jenis asli dan bukan asli, yang dimanfaatkan bagi kepentingan penelitian, ilmu pengetahuan, pendidikan, menunjang budidaya, budaya, pariwisata dan rekreasi dan kawasan pelestarian alam merupakan kawasan dengan ciri khas tertentu, baik di darat maupun di perairan yang mempunyai fungsi perlindungan sistem penyangga kehidupan, pengawetan keanekaragaman jenis tumbuhan dan satwa serta pemanfaatan secara lestari sumber daya alam hayati dan ekosistemnya.

Tingginya ketergantungan masyarakat terhadap hutan mangrove, mengharapkan adanya perlindungan dan pengelolaan Hutan Mangrove yang melibatkan peran masyarakat secara aktif. Masyarakat Bali berusaha untuk menerapkan asas keberlanjutan dalam memanfaatkan hutan mangrove, yakni, lingkungan hidup bukanlah warisan dari nenek moyang, melainkan suatu 'titipan' bagi anak cucu. Meskipun berdasarkan peraturan yang berlaku pengelolaan Taman Hutan Raya atau Tahura terbatas pada kegiatan penelitian, ilmu pengetahuan, pendidikan, menunjang budidaya, budaya, pariwisata dan rekreasi, namun dalam kenyataannya terdapat masyarakat atau kelompok masyarakat yang berkegiatan diluar kegiatan yang diperbolehkan oleh Undang-Undang yang beralokasi di dalam kawasan Tahura. Pemerintah Pusat sejatinya telah membentuk berbagai regulasi untuk melindungi dan mengelola mangrove, salah satunya adalah Peraturan Presiden Republik Indonesia Nomor 73 Tahun 2012 tentang Strategi Nasional Pengelolaan Ekosistem Mangrove yang mengatur mengenai Strategi Nasional Pengelolaan Ekosistem Mangrove. Namun dalam kenyataannya, perlindungan dan pengelolaan hutan mangrove belum terlaksana dengan baik. Seperti masih adanya oknum-oknum yang mencoba mengais keuntungan dari Hutan Mangrove dengan tidak sesuai aturan yang telah ditentukan dengan penyerobotan lahan kawasan hutan mangrove, pemanfaatan lahan untuk keperluan yang tidak sesuai peruntukkannya, seperti untuk lapangan bola, dan lain sebagainya. Begitu pula dengan Hutan Mangrove yang terletak di Provinsi Bali yang sangat luas, flora dan fauna yang melimpah dan memiliki lokasi yang strategis. Selain itu ada pula berbagai permasalahan seperti perambahan, pencemaran, aktivitas penduduk di sekitar kawasan, pembuangan sampah, penebangan, adanya sampah kiriman akibat pembuangan sampah ke badan sungai yang bermuara di kawasan mangrove terutama sampah plastik.

\section{Rumusan Masalah}

Berdasarkan latar belakang yang telah diuraikan, maka dapat dirumuskan permasalahan yang akan dikaji yakni, bagaimana urgensi pembentukan Peraturan Daerah Provinsi Bali tentang perlindungan dan pengelolaan hutan mangrove berlandaskan kearifan lokal?

\section{METODE PENELITIAN}

Penelitian ini menggunakan metode penelitian hukum normatif empiris. Dalam hal ini yang ingin dikaji adalah bagaimana perlindungan dan pengelolaan hutan mangrove di Provinsi Bali saat ini dihubungkan dengan regulasi yang telah ada saat ini dan bagaimana perlindungan dan pengelolaan hutan mangrove dapat dilakukan berdasarkan kearifan lokal di Wilayah Provinsi Bali. Spesifikasi penelitian ini adalah deskriptif dan analitis dengan teknik pengolahan ini menggambarkan gejala-gejala di lingkungan masyarakat terhadap suatu kasus yang diteliti, dan dengan analisis data yang kualitatif yang merupakan tata cara penelitian yang menghasilkan data deskriptif (Ridwan, 2011). 
Dalam penelitian ini, teknik yang digunakan adalah wawancara, berupa In-Depth Interview (wawancara mendalam) dan studi literatur. In-Depth Interview adalah proses memperoleh keterangan untuk tujuan penelitian dengan cara tanya jawab sambil bertatap muka antara pewawancara dengan responden atau orang yang diwawancarai, dengan atau tanpa menggunakan pedoman wawancara di mana informan terlibat dalam kehidupan sosial yang relatif lama (Sutopo, 2002). Dalam Penelitian ini, Peneliti melakukan penelitian kepada adalah instansi-instansi yang memiliki data-data dan keterangan dari pihak-pihak yang memiliki kewenangan dan keahlian dalam menjawab kompleksitas penelitian ini yaitu, Dinas Kehutanan Provinsi Bali, Dinas Lingkungan Hidup Provinsi Bali, Badan Pertanahan Provinsi Bali, dan Conservation International.

Penelitian ini menggunakan teknik pengolahan data deskriptif dan analitis yang menggambarkan gejala-gejala di lingkungan masyarakat terhadap suatu keadaan yang diteliti, dan dengan analisis data kualitatif yang merupakan tata cara penelitian yang menghasilkan data deskriptif (Soekanto, 1986)

\section{HASIL DAN PEMBAHASAN}

\section{Hutan Mangrove dan Pemanfaatannya}

Hutan dapat dibedakan menjadi 3 jenis berdasarkan fungsi pokoknya, yakni: Hutan Konservasi, Hutan Lindung dan Hutan Produksi. Hal ini termaktub dalam Pasal 6 ayat (2) Undang-Undang Nomor 41 Tahun 1991 tentang Kehutanan. Pembagian hutan berdasarkan fungsinya ini, khusus untuk hutan mangrove yang ada di bali terbagi menjadi 3 jenis pula, yakni ada hutan mangrove yang berada dalam status hutan konservasi, berada dalam status hutan lindung dan dalam status hutan produksi. Hutan mangrove yang berada dalam status hutan konservasi hanya Taman Hutan Raya Ngurah Rai, sedangkan hutan mangrove yang lainnya berada dalam status hutan lindung maupun hutan produksi.

Berdasarkan Arah Kebijakan Strategi Nasional Pengelolaan Ekosistem sebagaimana tertuang dalam Lampiran Peraturan Presiden Nomor 73 Tahun 2012 tentang Strategi Nasional Pengelolaan Ekosistem Mangrove, dinyatakan bahwa terdapat Peningkatan kapasitas Pemerintah Daerah dalam melaksanakan kewenangan dan kewajiban pengelolaan ekosistem mangrove sesuai dengan kondisi dan aspirasi lokal. Hal ini telah dijaminkan dalam Pasal 9 ayat (1) Peraturan Presiden Nomor 73 Tahun 2012 tentang Strategi Nasional Pengelolaan Ekosistem (SNPEM) Mangrove yang menyatakan bahwa dalam melaksanakan SNPEM di Provinsi, Gubernur menetapkan Strategi Pengelolaan Ekosistem Mangrove Tingkat Provinsi dan membentuk tim Koordinasi Strategi Pengelolaan Ekosistem Mangrove Tingkat Provinsi, Lebih lanjut dalam ayat (2) dinyatakan bahwa untuk mendukung pelaksanaan tugas Tim Koordinasi Strategi Pengelolaan Ekosistem Mangrove Tingkat Provinsi, Ketua Tim Koordinasi Strategi Pengelolaan Ekosistem Mangrove Provinsi membentuk Kelompok Kerja Mangrove Tingkat Provinsi. SNPEM diartikan dalam Pasal 1 ayat (1) sebagai upaya dalam bentuk kebijakan dan program untuk mewujudkan pengelolaan ekosistem mangrove lestari dan masyarakat sejahtera berkelanjutan berdasarkan sumber daya yang tersedia sebagai bagian integral dari sistem perencanaan pembangunan nasional.

Pada Pasal 3 ayat (1) Peraturan Pemerintah Nomor 24 Tahun 2010 tentang Penggunaan Kawasan Hutan menjelaskan secara eksplisit bahwa penggunaan sebagian kawasan hutan untuk kepentingan pembangunan di luar kegiatan hutan hanya dapat dilakukan didalam: a. kawasan hutan produksi; dan/atau b. kawasan hutan lindung. Lebih lanjut pada ayat (2) dinyatakan 
bahwa penggunaan kawasan hutan sebagaimana dimaksud pada ayat (1) dilakukan tanpa mengubah fungsi pokok kawasan hutan dengan mempertimbangkan batasan luas dan jangka waktu tertentu serta kelestarian lingkungan. Mengenai penggunaan kawasan hutan ini pun dijelaskan dalam Pasal 4 ayat (1) Peraturan Pemerintah Nomor 61 Tahun 2012 tentang Perubahan Atas Peraturan Pemerintah Nomor 24 Tahun 2010 tentang Penggunaan Kawasan Hutan, bahwa penggunaan kawasan hutan untuk kepentingan pembangunan di luar kegiatan kehutanan hanya dapat dilakukan untuk kegiatan yang mempunyai tujuan strategis yang tidak dapat dielakkan, sebagaimana termaktub dalam ayat (2) nya yakni religi; pertambangan; instalasi pembangkit, transmisi, dan distribusi listrik, serta teknologi energy baru dan terbarukan; pembangunan jaringan telekomunikasi, stasiun pemancar radio, dan stasiun relay televisi; jalan umum, jalan tol, dan jalur kereta api; sarana transportasi yang tidak dikategorikan sebagai saran transportasi umum untuk keperluan pengangkutan hasil produksi; sarana dan prasarana sumber daya air, pembangunan jaringan instalasi air, dan saluran air bersih dan/atau air limbah; fasilitas umum; industri selain industri primer hasil hutan; pertahanan dan keamanan; prasarana penunjang keselamatan umum; penampungan sementara korban bencana alam; atau pertanian tertentu dalam rangka ketahanan pangan dan ketahanan energi.

Lebih lanjut pada Pasal 6 ayat (1) Peraturan Pemerintah Nomor 24 Tahun 2010 menyatakan bahwa dalam penggunaan kawasan hutan dilakukan berdasarkan izin pinjam pakai kawasan hutan, yang dimana izin pinjam pakai kawasan hutan ini diberikan berdasarkan permohonan oleh Menteri Lingkungan Hidup dan Kehutanan, sebagaimana termaktub dalam Pasal 7 ayat (1) Peraturan Pemerintah Nomor 24 Tahun 2010. Diatur lebih lanjut dalam ayat (2), bahwa Pelimpahan wewenang pemberian izin pinjam pakai kawasan hutan dilakukan oleh Menteri kepada gubernur untuk pembangunan fasilitas umum yang sifatnya adalah nonkomersial.

Bagi kawasan hutan konservasi, tidak dapat diberikan izin pinjam pakai untuk penggunaan kawasan hutannya. Namun, kawasan hutan konservasi dapat diadakan kerjasama guna mewujudkan penguatan tata kelola pengelolaan kawasan dan konservasi keanekaragaman hayati, atau yang dikenal sebagai tujuan kerjasama penyelenggaraan Kawasan Suaka Alam (KSA) dan Kawasan Pelestarian Alam (KPA), sebagaimana diatur dalam Pasal 2 Peraturan Menteri Kehutanan Nomor P.85/MENHUT-II/2014 tentang Tata Cara Kerjasama Penyelenggaraan Kawasan Suaka Alam dan Kawasan Pelestarian Alam. Lebih lanjut pada Pasal 3, dinyatakan bahwa kerjasama penyelenggaraan KSA dan KPA ini meliputi penguatan fungsi KSA dan KPA serta konservasi keanekaragaman hayati dan pembangunan strategis yang tidak dapat dielakkan. Dalam hal penguatan fungsi KSA dan KPA serta konservasi keanekaragaman hayati, Pasal 6 ayat (1) Peraturan Menteri Kehutanan Nomor P.44/MENLHK/SETJEN/KUM.1/6/2017 tentang Perubahan Atas Peraturan Menteri Kehutanan Nomor P.85/MENHUT-II/2014 tentang Tata Cara Kerjasama Penyelenggaraan Kawasan Suaka Alam dan Kawasan Pelestarian Alam, mengkategorikan jenis kerjasama yang dimaksud, yakni kerja sama penguatan kelembagaan, kerja sama perlindungan kawasan, kerja sama pengawetan flora dan fauna, kerja sama pemulihan ekosistem, kerja sama pengembangan wisata alam, kerja sama pemberdayaan masyarakat, kerja sama pemasangan/penanaman pipa instalasi air, dan Kerja sama kemitraan konservasi. Sedangkan dalam hal pembangunan strategis yang tidak dapat dielakkan, Pasal 13 mengkategorikan jenis kerjasama yang dimaksud, yakni kegiatan yang mempunyai pengaruh terhadap kedaulatan negara dan pertahanan keamanan negara; pemanfaatan dan pengembangan sarana komunikasi dan pendukungnya; pemanfaatan dan pengembangan transportasi terbatas; pemanfaatan dan pengembangan energi baru dan terbarukan serta jaringan listrik untuk kepentingan nasional; dan kerja sama dalam rangka mitigasi bencana. 


\section{Kerusakan dan Permasalahan Yang Terjadi Pada Hutan Mangrove di Bali}

Mangrove yang berada di Provinsi Bali sebagian besar hidup di dalam kawasan hutan. Hutan Mangrove terluas terdapat pada Taman Hutan Raya (Tahura) Ngurah Rai yakni seluas 1.373,5 ha, dimana sebagian terdapat di kawasan Taman Nasional Bali Barat yakni seluas 633,5 ha dan di Kabupaten Klungkung, yang merupakan hutan lindung, seluas 202 ha. Selebihnya, hutan mangrove tersebar diluar kawasan hutan yang senyatanya masih masuk kedalam kawasan hutan lindung. Berikut kondisi hutan mangrove di Provinsi Bali yang dicatat oleh Pusat Pengendalian Pembangunan Ekoregion Bali dan Nusa Tenggara:

Tabel 1 Kondisi Hutan Mangrove di Provinsi Bali

\begin{tabular}{|c|c|c|c|c|}
\hline NO. & KAB/KOTA & KEKRITISAN & FUNGSI KAWASAN & LUAS (HA) \\
\hline \multirow[t]{7}{*}{1.} & \multirow[t]{7}{*}{ Badung } & \multirow[t]{2}{*}{ Rusak } & APL & - \\
\hline & & & Lindung & 172,0 \\
\hline & & \multicolumn{2}{|l|}{ Total Rusak } & 172,0 \\
\hline & & \multirow[t]{2}{*}{ Tidak Rusak } & APL & - \\
\hline & & & Lindung & 581,5 \\
\hline & & \multicolumn{2}{|l|}{ Total Tidak Rusak } & 581,5 \\
\hline & & \multicolumn{2}{|l|}{ Total Badung } & 753,5 \\
\hline \multirow[t]{7}{*}{2.} & \multirow[t]{7}{*}{ Buleleng } & \multirow[t]{2}{*}{ Rusak } & APL & 31,0 \\
\hline & & & Lindung & 97,5 \\
\hline & & \multicolumn{2}{|l|}{ Total Rusak } & 128,5 \\
\hline & & \multirow[t]{2}{*}{ Tidak Rusak } & APL & - \\
\hline & & & Lindung & 114,5 \\
\hline & & \multicolumn{2}{|l|}{ Total Tidak Rusak } & 114,5 \\
\hline & & \multicolumn{2}{|l|}{ Total Buleleng } & 243,0 \\
\hline \multirow[t]{7}{*}{3.} & \multirow[t]{7}{*}{ Denpasar } & \multirow[t]{2}{*}{ Rusak } & APL & - \\
\hline & & & Lindung & 81,4 \\
\hline & & \multicolumn{2}{|l|}{ Total Rusak } & 81,4 \\
\hline & & \multirow[t]{2}{*}{ Tidak Rusak } & APL & 21,0 \\
\hline & & & Lindung & 538,6 \\
\hline & & \multicolumn{2}{|l|}{ Total Tidak Rusak } & 559,6 \\
\hline & & \multicolumn{2}{|l|}{ Total Denpasar } & 641,0 \\
\hline \multirow[t]{7}{*}{4.} & \multirow[t]{7}{*}{ Jembrana } & \multirow[t]{2}{*}{ Rusak } & APL & 29,5 \\
\hline & & & Lindung & 34,0 \\
\hline & & \multicolumn{2}{|l|}{ Total Rusak } & 63,5 \\
\hline & & \multirow[t]{2}{*}{ Tidak Rusak } & APL & 115,0 \\
\hline & & & Lindung & 183,0 \\
\hline & & \multicolumn{2}{|l|}{ Total Tidak Rusak } & 298,0 \\
\hline & & \multicolumn{2}{|l|}{ Total Jembrana } & 361,5 \\
\hline \multirow[t]{7}{*}{5.} & Klungkung & Rusak & APL & 9,5 \\
\hline & & & Lindung & - \\
\hline & & Total Rusak & & 9,5 \\
\hline & & Tidak Rusak & APL & 5,0 \\
\hline & & & Lindung & 202,0 \\
\hline & & Total Tidak Rusak & & 207,0 \\
\hline & & Total Klungkung & & 216,5 \\
\hline
\end{tabular}

Sumber: Pusat Pengendalian Pembangunan Ekoregion Bali dan Nusa Tenggara, 2015 
Taman Hutan Raya atau yang disingkat sebagai Tahura diartikan oleh Mega Lugina, dkk (2017) sebagai kawasan pelestarian alam, memiliki fungsi perlindungan sistem penyangga kehidupan, pengawetan keanekaragaman jenis tumbuhan dan satwa, serta pemanfaatan secara lestari sumber daya alam hayati dan ekosistemnya. Berbagai jenis kegiatan yang dilakukan didalam lingkungan Tahura Ngurah Rai, harus dilakukan tanpa mengurangi fungsi pokok masing-masing kawasan. Sebagaimana telah diketahui bahwa pengelolaan kawasan Tahura Ngurah Rai dibagi dalam blokblok kegiatan meliputi blok perlindungan, blok pemanfaatan, dan blok lainnya (khusus; religi, budaya dan sejarah; rehabilitasi; dan tradisional).

Dengan adanya pembagian blok-blok atau zona-zona tersebut, sesuai dengan Pasal 33 ayat (3) Undang-Undang Nomor 5 Tahun 1990 dikatakan bahwa setiap orang dilarang melakukan kegiatan yang tidak sesuai dengan fungsi zona pemanfaatan dan zona lain yang ada didalam Tahura Ngurah Rai. Sehingga dalam pengelolaannya haruslah disesuaikan dengan fungsi-fungsi setiap zonanya. Didalam Tahura Ngurah Rai, senyatanya Pemerintah dapat memberikan hak pengusahaan atas zona pemanfaatan untuk sarana kepariwisataan dan rekreasi selama pemanfaatan lahan tersebut berada dalam zona pemanfaatan Tahura dan harus didasarkan pada rencana pengelolaan, hal ini sesuai dengan yang dijaminkan dalam Pasal 34 ayat (2) dan (3) Undang-Undang Nomor 5 Tahun 1990. Lebih dalam diatur pada Pasal 36 (1) Peraturan Pemerintah Nomor 28 Tahun 2011 tentang Pengelolaan Kawasan Suaka Alam dan Kawasan Pelestarian Alam, mengenai jenis pemanfaatan yang dapat dilakukan di Tahura, yakni terbatas pada kegiatan penelitian, pengembangan ilmu pengetahuan dan teknologi; pendidikan; koleksi keanekaragaman hayati; penyimpanan/ penyerapan karbon, pemanfaatan air/energi air, panas, dan angin serta wisata alam; pemanfaatan tumbuhan dan satwa liar dalam rangka budidaya; pemanfaatan tradisional oleh masyarakat setempat; dan penangkaran satwa/perbanyakan tumbuhan. Sedangkan pemanfaatan tradisional yang dimaksud yaitu pemungutan hasil hutan bukan kayu, budidaya tradisional, serta perburuan tradisional terbatas hanya untuk jenis yang tidak dilindungi.

Terdapat beberapa permasalahan-permasalahan yang kerap ditemui dalam pemanfaatan kawasan Tahura Ngurah Rai yang tercatat dalam buklet Tahura yang diterbitkan oleh BPKH Wilayah VIII Denpasar, yakni: Perambahan 0,35 ha; kawasan dimohonkan tukar menukar seluas 7,7160 ha; disertifikatkan masyarakat 1,166 ha. Permasalahan yang terjadi di kawasan Tahura Ngurah Rai adalah sebagai berikut:

1. Adanya penggunaan kawasan hutan yang berada di luar kegiatan kehutanan Tahura Ngurah Rai cukup luas, sehingga fungsinya tidak optimal;

2. Penyerobotan lahan untuk berbagai kepentingan baik kepentingan sosial, umum, maupun pribadi, yang telah terjadi pada beberapa lokasi di Tahura Ngurah Rai;

3. Ketidak sesuaian dalam pemanfaatan kawasan Tahura Ngurah Rai seperti menjadi lapangan sepak bola, TPA sampah maupun tanah urug oleh penduduk;

4. Belum terselesaikannya permasalahan mengenai pensertifikatan tanah pada kawasan Tahura Ngurah Rai, sehingga masih berada dalam proses hukum;

5. Penggunaan kawasan hutan di luar kegiatan kehutanan dengan izin pinjam pakai dengan masa perjanjian telah habis maupun yang masih berlaku di Tahura Ngurah Rai, perlu diperbaharui dan disempurnakan;

6. Penerapan tata ruang yang belum efektif, sehingga terjadi inkonsistensi serta tumpang tindih dalam pembangunan fisik dan aktivitas lainnya dalam wilayah pesisir pantai sebagai habitat dari hutan mangrove; 
7. Tapal batas kawasan Tahura Ngurah Rai telah ditetapkan, namun beberapa titik lokasi rawan terhadap penyerobotan lahan, dikarenakan pengawasan di lapangan tidak ketat, batas tidak permanen, dan belum dilakukan registrasi posisi geografis (melalui ordinat bumi);

8. Kurang berperannya lembaga yang khusus menangani masalah hukum, perizinan, dan pelanggaran di Tahura Ngurah Rai.

Berdasarkan hasil wawancara dengan I Putu Agus Juliartawan selaku Kepala Seksi Perencanaan dan Tata Hutan, Dinas Kehutanan Provinsi Bali, didapatkan, dijelaskan bahwa di lapangan masih kerap terjadi penyerobotan lahan Tahura Ngurah Rai dikarenakan pembangunan rumah, hotel, dan sebagainya. Di mana hal ini terjadi dikarenakan adanya tumpang tindih atas sertifikat yang diterbitkan oleh Badan Pertanahan Nasional. Berawal saat diterbitkannya sertifikat oleh Badan Pertanahan Nasional yang telah dianggap luas lahan dalam sertifikat tersebut diluar kawasan Tahura (dalam area perbatasan), namun saat tahap pembangunan, baru terlihat jelas bahwa bangunan dibangun melewati batas dari batas lahan yang tertera dalam sertifikat. Menurutnya, tidak ada patok pembatas yang jelaslah yang menjadi penyebab utama kerap terjadinya penyerobotan lahan ini. Terlihatnya penyerobotan lahan ini pun diketahui setiap rekonstruksi batas wilayah Tahura yang dilakukan setiap 5 tahun sekali. Bahkan banyak terjadi pelanggaran rumah permanen tanpa izin dalam kawasan hutan mangrove (seperti di sekitar TPA Badung, di tempat penangkaran penyu telah terdapat cukup banyak bangunan permanen untuk restoran, tempat peristirahatan, tempat parkir dan sebagainya, balai kelompok nelayan di sekitar Pura Karangasem Kelurahan Tuban, Kedonganan dan di tempat lainnya). Selain itu, ada pulapembangunan jalan tol Nusa Dua Benoa-Ngurah Rai yang melewati hutan mangrove, dan terdapat pengurugan kapur.

Selain itu, BPKH Wilayah VIII Denpasar kembali menjelaskan mengenai upaya rehabilitasi, pemeliharaan, dan perlindungan/pelestarian kawasan hutan mangrove belum banyak melibatkan masyarakat secara efektif, padahal hal tersebut telah dijaminkan dalam Undang-Undang Nomor 5 Tahun 1990. Selama ini masyarakat adat Bali masih belum banyak yang dilibatkan dalam sosialisasi sehingga masih banyak terjadi permasalahan yakni $\mathrm{P}=$ perlindungan yang melibatkan Lembaga Swadaya Masyarakat Pelaku Usaha dan Masyarakat Wilayah Pesisir Pantai sebagai habitat hutan mangrove di dalam kawasan hutan maupun di luar kawasan hutan sebagai hutan hak dan sebagai kawasan peruntukan umum belum berjalan efektif, pembinaan kepada masyarakat di wilayah pesisir pantai dan penegakan hukum terhadap semua bentuk pelanggaran belum berjalan efektif, pengawasan terhadap pelanggaran yang terjadi baik dalam bentuk perambahan hutan, pengurugan, perluasan pinjam-pakai maupun pensertifikatan yang dilakukan oleh perorangan, instansi pemerintah, maupun swasta belum efektif, pengetahuan dan pemehaman masyarakat di wilayah pesisir pantai terhadap fungsi dan manfaat hutan mangrove kurang disosialisasikan, fungsi dan manfaat hutan mangrove secara keseluruhan belum dapat ditunjukkan secara nyata untuk dikembangkan menjadi usaha yang dapat meningkatkan kesejahtraan masyarakat di wilayah pesisir pantai. Namun di beberapa tempat sudah dirasakan manfaatnya oleh kelompok masyarakat, kerjasama multi Steakholder, Lembaga Swadaya Masyarakat dan Kelompok Masyarakat di wilayah pesisir pantai belum berjalan baik, upaya rehabilitasi dan pemeliharaan yang dilakukan untuk mengimbangi laju kerusakan habitat hutan mangrove belum optimal dilakukan dengan melibatkan masyarakat. 


\section{Urgensi Pembentukan Peraturan Daerah Provinsi Bali Tentang Perlindungan Dan Pengelolaan Hutan Mangrove Berlandaskan Kearifan Lokal}

Sebagaimana bentuk negara Indonesia sebagai negara hukum yang diindahkan Dalam hal memberikan payung hukum yang lebih terkhususkan untuk perlindungan dan pengelolaan hutan mangrove di provinsi Bali maka dibutuhkan adanya pembentukan peraturan daerah yang dalam perumusannya menganut unsur kearifan lokal yang dianut oleh masyarakat hukum adat Bali. Berdasarkan Pasal 35 Undang-Undang Nomor 12 Tahun 2011, dikatakan bahwa penyusunan rancangan peraturan daerah provinsi didasarakan atas perintah peraturan perudang-undangan lebih tinggi, rencana pembangunan daerah, penyelenggaraan otonomi daerah dan tugas pembantuan, dan aspirasi masyarakat daerah. Sehingga demi adanya perlindungan yang lebih efektif dalam hal perlindungan dan pengelolaan hutan mangrove, baik dalam bentuk hutan lindung maupun hutan konservasi, maka dibutuhkan adanya peraturan daerah sebagai suatu rencana pembangunan daerah.

Mengenai penyelenggaraan kehutanan bahkan telah diatur mengenai penyerahan kewenangan dari Pemerintah Pusat kepada Pemerintah Daerah didalam Undang-Undang Nomor 41 Tahun 1999 tentang Kehutanan.Penyerahan kewenangan dari Pemerintah Pusat terhadap Pemerintah Daerah mengenai pengurusan kehutanan ini dengan tujuan untuk meningkatkan efektivitas pengurusan hutan dalam rangka pengembangan otonomi daerah.

Selain itu dalam pembentukan peraturan daerah ini, diperlukan adanya turut serta masyarakat dalam pengawasan kehutanan. Bahkan masyarakat bersama-sama Pemerintah dan Pemerintah Daerah melakukan pengawasan terhadap pengelolaan dan atau pemanfaatan hutan yang dilakukan oleh pihak ketiga. Dimana hal ini sebagai pencerminan Pasal 60 ayat (2) dan Pasal 62 Undang-Undang Nomor 41 Tahun 1999 tentang Kehutanan.Sebagaimana yang telah berlaku dalam mengawasi bahkan mengatur hutan desa di Desa Pakraman Selat Kecamatan Sukasada, yang dilakukan oleh Pecalang Jagawana (Christiawan, 2017). Pecalang diartikan sebagai kelompok penjaga keamanan tradisional di Bali. Pecalang Jagawana ini dinilai sangatlah efektif dalam menjaga hutan tersebut dari adanya pembalakan liar, dilihat dari keefektifannya dalam menjaga keamanan hutan yang mencapai $65,1 \%$ (Lugina dkk, 2017).

Urgensi pembentukan peraturan daerah ini dapat dinilai sebagai realisasi Pasal $28 \mathrm{H}$ ayat (1) Undang-Undang Dasar Negara Republik Indonesia Tahun 1945, yang bahwa setiap orang berhak hidup sejahtera lahir dan batin, bertempat tinggal, dan mendapatkan lingkungan hidup yang baik dan sehat serta berhak memperoleh pelayanan kesehatan. Pasal ini diilhami sebagai suatu hak dari masyarakat Bali mengenai lingkungan hidupnya, dalam hal ini adalah ekosistem mangrove. Selain demi memenuhi hak masyarakat, namun sebagai pengemban hak dan kewajiban, masyarakat pun harus diberikan kewajiban dalam mengawasi secara langsung maupun tidak langsung terhadap kawasan hutan mangrove, baik yang merupakan hutan dalam status hutan lindung, hutan produksi maupun dalam status hutan konservasi.

Peraturan Daerah Provinsi Bali mengenai perlindungan dan pengelolaan hutan mangrove ini baru menjadi perbincangan, dikarenakan berdasarkan hasil wawancara yang dilakukan bersama Conservation International Indonesia, Bali sedang dalam tahap untuk membentuk peraturan daerah mengenai pengakuan status masyarakat hukum adat terlebih dahulu, dimana hal ini pun tercermin pada Pasal 67 ayat (2) Undang-Undang Nomor 41 Tahun 1999 tentang Kehutanan. Hal ini dimaksudkan agar masyarakat hukum adat Bali memiliki payung hukum yang bersifat eksplisit dan memiliki kekuatan hukum yang tetap. Berdasarkan data yang didapat dari Dinas Kehutanan Provinsi Bali, sampai saat ini telah ada Rancangan Peraturan Daerah Provinsi Bali mengenai Perlindungan Hutan dan Pemanfaatan Kawasan Hutan. Kedua rancangan ini 
membahas mengenai kawasan hutan secara umum, belum terfokuskan pada hutan mangrove saja. Namun, menurut I Putu Agus Juliartawan selaku Kepala Seksi Perencanaan dan Tata Hutan, Dinas Kehutanan Provinsi Bali, diperlukan untuk adanya suatu peraturan daerah yang mengatur mengenai pengelolaan dan pengawasan hutan mangrove di Bali dengan melibatkan masyarakat hukum adat, memuat ketentuan pidana, dilandaskan pada kearifan lokal Bali seperti Tri Hita Karana yang berarti tiga penyebab keharmonisan, terdiri dari parahyangan, pawongan dan palemahan. Parahyangan berarti keharmonisan antara manusia dengan Ida Sang Hyang Widi Wasa Tuhan Yang Maha Esa; Pawongan merupakan keharmonisan antara manusia dengan sesame manusia, meliputi keluarga, teman dan masyarakat; dan Palemahan merupakan keharmonisan antara umat manusia dengan lingkungannya (Lugina dkk, 2017).

\section{KESIMPULAN DAN SARAN}

\section{Kesimpulan}

Hutan mangrove memiliki berbagai fungsi yang sangat penting diantaranya melindungi pantai dari abrasi, sebagai pemecah gelombang laut, sebagai penahan lumpur dan sedimen, menjaga kestabilan garis pantai, daerah pencari makanan dan daerah pemijahan bermacam biota perairan baik yang hidup di perairan maupun lepas pantai. Selain itu, hutan mangrove yang memiliki berbagai jenis kawasan, memiliki fungsi pokok yang tersendiri pula. Bagi hutan mangrove yang merupakan hutan konservasi memiliki fungsi yakni perlindungan sistem penyangga kehidupan, pengawetan keanekaragaman jenis tumbuhan dan satwa, serta pemanfaatan secara lestari sumber daya alam hayati dan ekosistemnya. Sedangkan bagi hutan mangrove yang merupakan hutan lindung atau hutan produksi dapat dilakukan pembangunan untuk diluar kegiatan kehutanan dengan adanya pemberian status/izin pinjam pakai.

Dalam kenyataannya, masih kerap terjadi pemanfaatan kawasan hutan mangrove yang di luar batasan-batasan pemanfaatan hutan mangrove yang telah dijaminkan dalam perundangundangan. Sebagai contoh, adanya penyerobotan lahan pada kawasan Tahura Ngurah Rai, yang merupakan kawasan hutan mangrove dengan status hutan konservasi, lalu masih kerap terjadi pula adanya tumpang tindih antara sertifikat yang dikeluarkan Badan Pertanahan Nasional dengan lebar lahan yang digunakan oleh pihak ketiga, dan lain sebagainya.

Masyarakat adat Bali pun senyatanya telah dijaminkan dalam Undang-Undang Nomor 41 Tahun 1999 tentang Kehutanan untuk turut berpartisipasi dalam mengawasi pengelolaan dan pemanfaatan dari hutan mangrove di Bali. Sebagaimana yang telah ada di Desa Pakraman Selat Kecamatan Sukasada, Pecalang Jagawana yang bertugas dalam menjaga keamanan hutan desanya dari adanya pembalakan liar, dan penjagaannya ini berhasil dan terbukti efektif.

\section{Saran}

Dengan adanya Peraturan Daerah Provinsi Bali yang secara khusus mengatur mengenai perlindungan dan pengelolaan hutan mangrove berlandaskan kearifan lokal, sangatlah dibutuhkan selama di dalam peraturan daerah ini mensisipkan mengenai keikutsertaan masyarakat dalam hal tersebut. Walau peran masyarakat sejatinya telah diindahkan dalam peraturan perundang-undangan yang telah ada, namun dalam kenyataannya hal tersebut terbukti belum efektif. Sehingga dengan adanya suatu legislasi khusus dapat disesuaikan dengan keadaan dan kondisi yang ada di Bali itu sendiri. Dikarenakan pembentukan peraturan daerah sebagaimana yang dipahami dalam Undang-Undang Nomor 12 Tahun 2011 didasarkan pada Perintah peraturan perundang-undangan lebih tinggi; Rencana pembangunan daerah; Penyelenggaraan otonomi daerah dan tugas pembantuan; dan Aspirasi masyarakat daerah, demi 
terciptanya perlindungan yang lebih efektif dalam hal perlindungan dan pengelolaan hutan mangrove, baik dalam bentuk hutan lindung maupun hutan konservasi, maka dibutuhkan adanya peraturan daerah sebagai suatu rencana pembangunan daerah.

\section{Ucapan Terima Kasih}

Penulis mengucapkan terima kasih yang sebesar-besarnya kepada Direktorat Penelitian dan Pengabdian Kepada Masyarakat Universitas Tarumanagara selaku pemberi dana penelitian dan kepada para narasumber yakni Bapak I Putu Agus Juliartawan selaku Kepala Seksi Perencanaan dan Tata Hutan Dinas Kehutanan Provinsi Bali, Dra. Ni Nyoman Wiratni selaku sekretaris Dinas Lingkungan Hidup Provinsi Bali, Bapak I Made Iwan Dewantama selaku manager Conservation International dan Bapak I Ketut Jiwa Sucahyana selaku Kepala Seksi Pengadaan dan Penetapan Tanah Pemerintah Badan Pertanahan Nasional Provinsi Bali.

\section{REFERENSI}

BPKH wilayah VIII Denpasar. Buklet Tahura. BPKH Wilayah VIII Denpasar, Denpasar.

Christiawan, P. I. (2017). The role of local wisdom in controlling deforestation. International Journal of Development and Sustainability, 6(8), 882.

Lugina, M., Alviya, I., Indartik, \& Pribadi, M. A. (2017). Strategi keberlanjutan pengelolaan hutan mangrove di Tahura Ngurah Rai. Jurnal Analisis Kebijakan Kehutanan, 14(1), 62.

Madjid, I., Al Muhdar, M. H. I., Rohman, F., \& Syamsuri, I. (2016). Konservasi hutan mangrove di pesisir pantai kota Ternate terintegrasi dengan kurikulum sekolah. Jurnal BIOeduKASI, 4(2), p. 488.

Pusat Pengendalian Pembangunan Ekoregion Bali dan Nusa Tenggara. (2015). Buku Saku Data Kehutananan Provinsi Bali. Pusat Pengendalian Pembangunan Ekoregion Bali dan Nusa Tenggara, Denpasar.

Ridwan. (2011). Hukum administrasi negara. Jakarta: Raja Grafindo.

Soekanto, S. (1996). Pengantar penelitian hukum. Jakarta: UI Press.

Sutopo. (2002). Metodologi penelitian kualitatif. Surakarta: Universitas Sebelas Maret Press. 